\title{
The Effect of Ethnic Diversity on Expenditure Inequality in Indonesia
}

${ }^{*}$ Martin, Budi

University of Indonesia, Jakarta

\begin{tabular}{l}
\hline \hline ARTICLE DETAILS \\
\hline Article History \\
Published Online: \\
JIAE (Journal Indonesian \\
Applied Economic)
\end{tabular}

Keywords

ethnic diversity, expenditure

inequality, Indonesia

\section{"Corresponding Author \\ Email: \\ martinbudi@gmail.com}

\begin{abstract}
Based on the National Socio-Economic Survey (Susenas) and population census from 2010, this study examines the effect of ethnic diversity on expenditure inequality in Indonesia. This is achieved using the OLS estimation using ethnic fractionalization index (efi) and ethnic polarization index (epoi) as the proxy of ethnic diversity. Without the control variable, the ethnic fractionalization index is positive and significant in affecting expenditure inequality in Indonesia. Unlike the ethnic fractionalization index, the ethnic polarization index and expenditure inequality have an inverted U-shaped relationship. However, the effect of ethnic diversity is less significant when control variables are added to the estimation. Additionally, the effect of ethnic diversity loses its significance when incorporating regional dummies into the estimation. We found that all regional dummies significantly affect inequality and diminish the ethnic diversity effect. Finally, the inclusion of the interaction term between ethnic diversity proxy and regional dummies reveals an unexpected result. Though not significant, both interactions of the ethnic fractionalization index or the ethnic polarization index with regional dummies show a negative relationship.
\end{abstract}





\section{INTRODUCTION}

Indonesia's Gini Ratio reached 0.393 in 2020, and has remained steady over 0.39 for the last 10 years. In 2011, Indonesia's inequality reached 0.4 as measured by the Gini ratio, and remained above 0.4 until 2018. According to the World Bank, a Gini ratio of 0.4 is very high among Asian countries, which is an alarming level. Therefore, how to reduce inequality is one of Indonesia's key policy issues. According to Figure 1.1, which presents the Gini ratio for urban and rural areas, urban area's Gini is always greater than the rural, reflecting types of economic activities in urban and rural areas. create an economic environment which encourages innovation and entrepreneurial activities, and this would, in turn, promotes economic development.

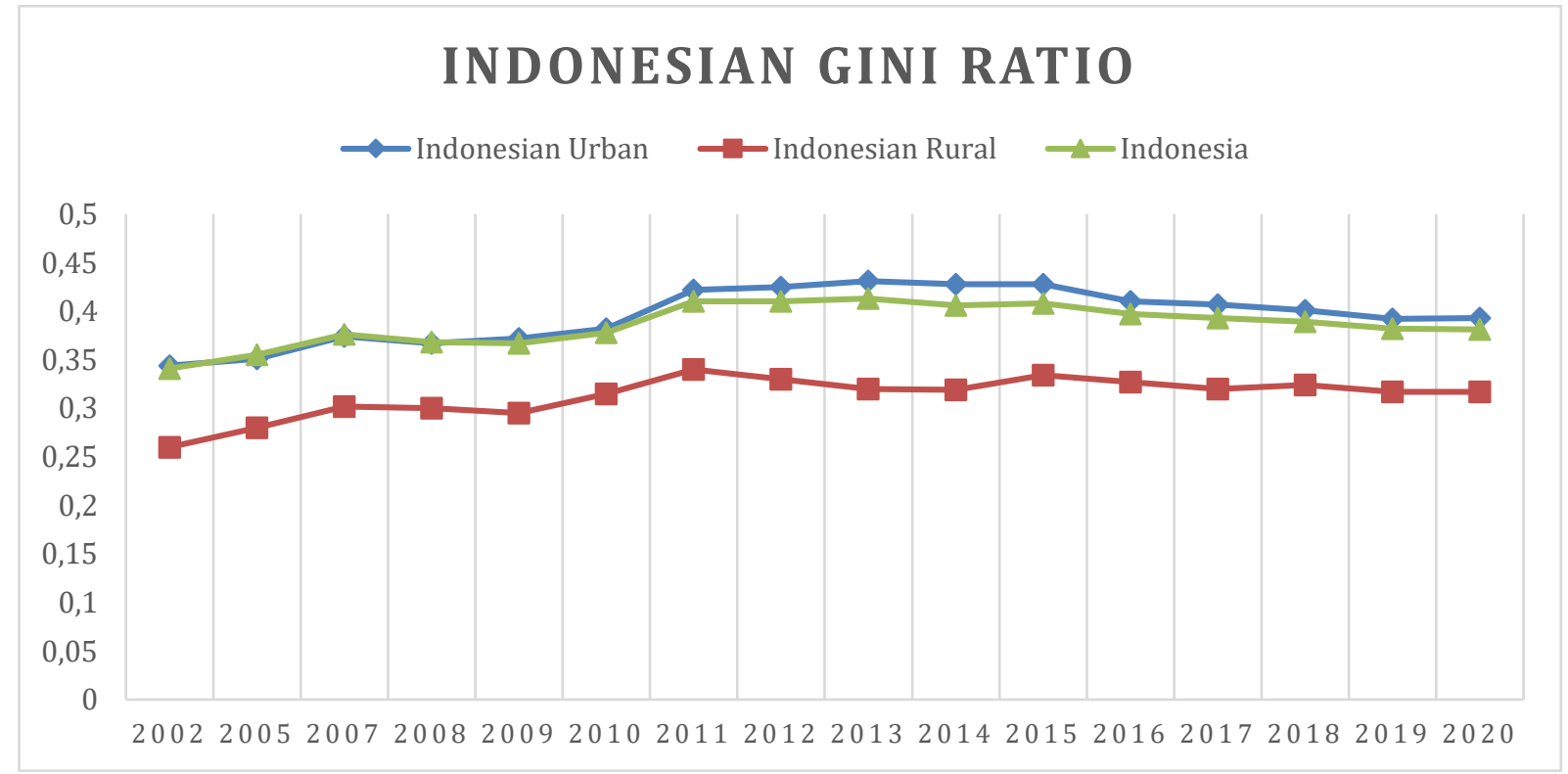

Figure 1.1 Gini Ratio in Urban and Rural

\section{Areas of Indonesia}

Source: Statistics Indonesia

Higher level of inequality has both positive and negative effects on the economy (Alesina, Michalopoulos, and Papaioannou , 2016). The negative side of a higher level of inequality is that it increases conflicts and crimes, prevents the poor from accessing education, and raises tax rates for higher income groups so that it might result in a reduced investment levels. On the other side, a higher level of inequality may
Besides income or expenditure inequality, Easterly and Levine (1997) argued that there is another factor that would affect economic performance, namely ethnic diversity. They found that in Africa, ethnic diversity and economic performance have a significant negative relationship; that is, a higher level of ethnic diversity is attached to poor economic performance. This study triggered researches on the interaction of ethnic diversity with economic development. Alesina et al. (2016) is considered to be the first study that investigated 


\section{The Effect of Ethnic Diversity on Expenditure Inequality in Indonesia}

the linkage between ethnic diversity and inequality using cross-country data. Using ethnolinguistic classification, they found that ethnic diversity appears to have had a negative impact on economic development. Besides its effects on economic performance, ethnic diversity is found to have been a source of conflict in society.

Meanwhile, Esteban, Mayoral, and Ray (2012) found a linear relationship between conflict and ethnic polarization and fractionalization and the Greenberg-Gini index among ethnic groups. They also found that ethnic polarization impacts more on public goods, while ethnic fractionalization affects private conflicts. On the other hand, Barron and Madden (2004) found that the most violent conflict in the province of Lampung in Indonesia was between ethnic groups and ethnic conflicts were a result of a complex collaboration between economic problems and the characteristics of ethnic groups.

Studies on ethnicity, particularly its effects on economic performance, were scarce in Indonesia. Ananta et al. (2015) and Arifin et al. (2015) focused on quantification of ethnic differences. As far as we know, Muller (2016) is the first study analyzed the interaction between economic distribution and ethnic diversity using household expenditure data, while Muttaqien, Sologon, and O'Donoghue, (2018) is the latest study that examined ethnic diversity and income polarization. Given this background, the objective of this study is to identify the effects of

\footnotetext{
${ }^{1}$ Banten, Riau Islands, Bangka Belitung, Gorontalo and West Papua were separated, respectively, from
}

Since the decentralization laws were enacted in 1999, there has been a proliferation of provinces and districts (kabupaten/kota). In 1999, Indonesia had 26 provinces with 268 regencies (kabupatens) and 73 municipalities (kotas). However, the number of provinces and districts have increased since then, and in 2010 , the country had 33 provinces, 399 regencies (kabupatens), and 98 municipalities (kotas). Fitrani, Hofman, and Kaiser (2005) argued that some of the factors for the proliferation of provinces and districts are geographic dispersion, political diversity, natural resources, and ethnic diversity. Gayatri (2011) found that since the decentralization was started in 1999 , the acknowledgment of ethnic differences has empowered ethnicity and has accelerated the proliferation of provinces and districts. For example, the provinces of Banten, Riau Islands, Bangka Belitung, Gorontalo, and West Papua have been established by splitting provinces because the people in these new provinces felt that they are ethnically different. ${ }^{1}$

ethnic diversity on expenditure inequality in Indonesia, in which the following two hypotheses are tested using the National Socioeconomic Survey (Susenas), and the population census in 2010: (1) ethnic polarization affects expenditure inequality positively, and (2) ethnic fractionalization has a positive and diminishing influence on expenditure inequality.

\section{LITERATURE REVIEW}

West Java, Riau, South Sumatra, North Sulawesi and Papua. 
Inequality in Indonesia reached its peak in 2013, making inequality more visible in the public policy debate. Statistics Indonesia stated that the Gini coefficient rose by $32 \%$, from 0.32 in 2003 to 0.43 in 2013 (Yusuf, Sumner, \& Rum,2014). Numerous studies have been conducted to evaluate inequality in expenditure among households in Indonesia such as Akita, Lukman and Yamada (1999), Tadjoeddin, Suharyo and Mishra (2001), Akita and Alisjahbana (2002), Akita and Miyata (2008), Miranti, et al. (2014), Hayashi, Kataoka and Akita (2014), Yusuf, Sumner and Rum (2014), Yusuf and Sumner (2015) and Akita (2017). Most of these studies used the National Socioeconomic Survey (Susenas) on household expenditure to measure inequality in per capita expenditure. Some of the reasons why they used consumption data instead of income data are: (1) household expenditure is a better predictor of welfare level than income because household expenditure does not fluctuate much in the short run than household income and (2) household consumption expenditure in developing countries such as Indonesia is more reliable than income (Akita, Lukman, \& Yamada, 1999).

Among the researched on the correlation between ethnic diversity, inequality and poverty, Walle and Dileni (2001) found that demographic factors made ethnic minorities to have lower living standards than ethnic majorities in Vietnam. While Gradin (2015) found that in China, ethnic minorities have a higher incidence of poverty than other ethnical groups because they are likely to live in the least developed and mountainous areas which do not benefit economic growth. Imai, Gaiha, and Kang (2011) found that in Vietnam, ethnic minorities are poorer not only because they have unfavorable household attributes with respect to education, location and so on, but because the returns are lower for ethnic minorities than other ethnical groups.

Alesina and La Ferara (2015) surveyed studies on the relationship between ethnic diversity and economic performance and assessed the effects of ethnic diversity on economic performance from policy perspectives. They argued that ethnicity affects willingness to cooperate due to asymmetric information and different productivities. They also argued that heterogeneity might result in a lower provision of public goods since competing groups do not want to collaborate. Empirical evidence suggests that these effects exist internationally. However, heterogeneity is thought to have different effects among democratic countries.

Dincer and Hotard (2011) examined, using a data set for 58 countries for ten years, the nexus between ethnicity, religious diversity, and income inequality. They argued that there is a relationship between religious and ethnic diversity and social conflicts that leads to income inequality. They found that ethnic and religious polarization has a positive and significant relation to income inequality. They also found that ethnic and religious diversity appears to have an inverted U-shaped relationship with income inequality, as ethnic and religious diversity explains about $80 \%$ of the variation of the Gini coefficient when control variables are included. 
Chadha and Nandwani (2018) examined the interaction between ethnic fragmentation and inequality through public goods provision in India using the National Sample Survey data on consumption expenditure. Considering different castes as ethnic groups, they found that horizontal inequality among ethnic groups weakly influenced overall expenditure inequality, while inequality was higher in more fragmented districts.

Arifin et al. (2015) is the first study that measured ethnic diversity at the provincial and district level in Indonesia using the 2010 population census. They found that Indonesia is relatively ethnically fractionalized since the ethnic fractionalization index $(E F I)$ is 0.81 , but not polarized considering the ethnic polarization index (EPOI) is $0.5 .^{2}$ Meanwhile, based on Indonesia Family Life Survey (IFLS), Muller (2016) found that the levels of ethnic diversity are much smaller than economic inequality, whether fractionalization, polarization or horizontal inequality are used. Using the 2014/2015 IFLS, Muttaqien et al. (2018) analyzed the effect of ethnicity on the polarization of income in Indonesia and found that ethnicity had a significant effect on earnings polarization if no control variables are included in the estimation. Contrary, the effect is reduced when additional covariates are included and became less significant if regional characteristics were controlled.

\footnotetext{
${ }^{2}$ The definitions of the ethnic fractionalization index

${ }^{2}$ The definitions of the ethnic fractionalization index
(EFI) and the ethnic polarization index (EPOI) will be presented in the next chapter.
}

Most of the studies on ethnic diversity and economic inequality used cross-country data. However, these studies have weaknesses since each country has different ethnic characteristics and economic condition. Therefore, this study focuses on Indonesia and examines the effects of ethnic diversity on expenditure inequality. Indonesia is abundant in economic and demographic data and uses the ethnic classification, which is uniform across regions; thus, this study could obtain internally consistent results. Unlike Muller (2016) and Muttaqien et al. (2018), this study utilizes expenditure data from Susenas and the estimates of the ethnic diversity index by Arifin et al. (2015).

\section{DATA AND METHODOLOGY}

\subsection{Data}

This study uses household expenditure data from the National Socioeconomic Survey (Susenas) that has been conducted periodically by the Central Bureau of Statistics (BPS). Susenas includes data on demographic and socioeconomic variables for households. Susenas is a national-wide survey, which covers whole Indonesia, i.e., covers all provinces, districts, and subdistricts. This study uses Susenas for 2010, which includes 293,715 households. Using expenditure data from Susenas 2010, we estimate expenditure inequality by the Gini coefficient and the Theil Index for districts (kabupaten/kota). 
This study analyzes the effect of ethnic diversity on inequality. Since Susenas does not contain ethnicity variables, it uses the ethnic fractionalization index (EFI) and ethnic polarization index (EPOI) for 497 districts which were calculated by Arifin et al. (2015) using the population census in 2010 . It should be noted that the 2010 population census is the latest census that includes data on ethnicity variables. $\mathrm{EFI}$ is an index that measures the likelihood that two randomly selected individuals in a region belong to the same ethnic group. The EFI index is supposed to represent ethnic heterogeneity and ranges from 0 to 1 . A lower value of EFI indicates that the region is ethnically more homogeneous (or less heterogeneous), while a higher value of $\mathrm{EFI}$ indicates that the region is ethnically more heterogeneous (or less homogeneous).

Before calculating the EFI, the number of ethnic groups should be appropriately defined. The original 2010 population census includes 1331 ethnic groups. Since there are some misspelling and coding errors in classifying people into ethnic groups, Ananta et al. (2015) reclassified 1331 ethnic groups into around 600 groups and used all these ethnic groups to calculate EFI. The number of ethnic groups varies across districts.

Ethnic Polarization Index (EPOI) was proposed by Reynal-Querol (2002) depending on the polarization measure of Esteban and Ray (1994). Esteban and Ray (1994) indicated that when there are two or more ethnic groups of nearly the same size, society is polarized. The EPOI is used to capture the potential for racial antagonism resulting from two or more ethnic groups of the same size. The EPOI equals 1 (max value) when there are two different ethnic groups with an equal size of members and decline as the number of groups with different size increases. Ethnic polarization among ethnic groups might increase tension among these groups in the region. Therefore, ethnic polarization would have a significant and positive effect on the probability that civil wars occur and adverse effect on economic growth (Reynal-Querol, 2002). Hence Alesina and La Ferrara (2005) argued that a fractionalized region tends to be more stable than polarized regions.

Examining the effects of ethnic diversity on expenditure inequality, this study needs to estimate expenditure inequality for 497 districts. This study utilizes the two Theil indices and the Gini coefficient to measuring expenditure inequality since they satisfy the following four desirable features as a measure of inequality: anonymity, income homogeneity, population homogeneity, and the Pigue-Dalton principle of transfers (Anand,1983). Anonymity means that it does not matter who owns what incomes, namely, the index of inequality does not change when the owners of incomes change as long as the distribution of incomes remains the same. Income homogeneity implies that the index of inequality does not change even if incomes are altered by the same fraction, whereas population homogeneity implies that inequality index does not change even if the distribution of incomes is duplicated. Lastly, the Pigou-Dalton principle of transfers means that if there is a transfer of earnings from a richer individual to a poorer one, the index of inequality will decrease 
as long as the transfer does not alter the rank of these two individuals.

\subsection{Method}

This study observes the effect of ethnic diversity on expenditure inequality by using conducting a multiple regression analysis based on data for 497 districts. The regression model that we estimate is provided by:

$$
\gamma_{i}=\alpha+\beta X_{i}+\gamma \boldsymbol{Z}_{\mathbf{i}}+\epsilon_{i}
$$

where $i$ refers to district $i, \gamma_{i}$ is the dependent variable, $\alpha$ is the constant term, $X_{i}$ is a variable of ethnic diversity, and $Z_{i}$ refers to control variables.

\section{Dependent Variable}

As the dependent variable, the Theil L (theil_I), the Theil T (theil_t) or the Gini coefficient (gini) is used. These three inequality measures are calculated for 497 districts using expenditure data from Susenas in 2010.

\section{Independent Variable}

As a variable for ethnic diversity, this study uses ethnic fractionalization index (efi) or ethnic polarization index (epol). Values of these indices are obtained from Arifin et al. (2015). Meanwhile, the following variables are included as control variables.

(1) Natural logarithm of mean per capita expenditure (In_mean_pcexp)

According to Kuznets (1995), there is an inverted U-shaped relationship between expenditure or income inequality and the level of economic development. Since the natural logarithm of mean per capita expenditure is a proxy for economic development, this study includes the square of this variable to test whether there is the Kuznets's inverted U-shaped relationship between expenditure or income inequality and the level of economic development.

(2) Mean household size (mean_hsize)

Mean household size is the mean number of household members. The household expenditure per capita will decrease as the number of household sizes increases. Therefore it is expected that as the number of household members rises, expenditure inequality increases, namely, mean household size has a positive effect on expenditure inequality.

(3) The proportion of urban households (prop_urban)

The proportion of urban households is a proxy for urbanization rate. According to Sagala, Akita, and Yusuf (2014), in Indonesia, urbanization rate exceeds the level at which expenditure inequality attains the peak. According to the Kuznets' hypothesis, further urbanization would decrease expenditure inequality. Therefore, it is expected that the proportion of urban households has a negative relationship with expenditure inequality.

(4) The proportion of male headed households (prop_male)

According to the 1990 Population Census, male-headed households have higher levels of educational attainments than female-headed households. According to Akita et al. (1999), gender disparity in per capita expenditure constituted only $3-4 \%$ of overall expenditure inequality. Though it is unknown whether the proportion of maleheaded households has a significant 
positive or negative effect on expenditure inequality, this study includes this variable.

(5) Mean age (mean_age)

Mean age is the mean age of household heads. According to Akita et al. (1999), expenditure inequality is higher for older age groups. It is expected, therefore, this variable has a positive effect on expenditure inequality.

(6) Mean education (mean_edu)

Mean education is the mean of years of education that household heads completed. According to Akita (2017), expenditure inequality is higher for more educated groups. It is expected, therefore, that mean education has a positive effect on expenditure inequality.

(7) Log of total population (In_total_pop)

Log of total population is the natural logarithm of total population where data on population is obtained from the 2010 Population Census. Highly populated districts more likely to have diverse income and expenditure, therefore more populated regions tend to have higher inequality,so this variable has a positive effect on expenditure inequality.

(8) Poverty rate (pov)

Poverty rate is the incidence of poverty (namely, poverty headcount ratio) is the proportion of households under the poverty line divided by the total number of households. The increase number of poor households, ceteris paribus, will increase the gap between the rich and the poor and raise inequality thus, this variable has a positive effect on expenditure inequality.
A regression model in equation (1) is estimated using the Theil indices or Gini coefficient as the dependent variable. Since there is a crucial non-linear relationship between two ethnic diversity variables (EFI and EPOI); thus, as an independent variable, either EFI or EPOI is included in the regression analysis. However, the following regression model is also estimated using the method proposed by Mavridis (2015). $\gamma_{i}=\alpha+\beta_{0}$ divers $_{i}+\beta_{1}$ epoi $_{i}+\beta_{2}$ ef $i 3_{i}+\gamma Z_{i}+$ $\epsilon_{i}$

where:

$$
\begin{array}{ll}
i & =\text { districts } i \\
\gamma_{i} & =\text { the dependent variable; } \\
\text { divers }_{i} & =\text { efi }, \text { if efi }<0.6 ; \\
\text { epoi }_{i} & =\text { epoi }, \text { if epoi }>0.6 ; \\
\text { efi }_{i} & =\text { efi }, \text { if efi }>0.6 ; \text { and } \\
Z_{i} & =\text { control variables. }
\end{array}
$$

This method rectifies a collinearity problem associated with EFI and EPOI that occur when they have values under the threshold (here it is 0.6) (Arifin et al., 2015). Therefore this model separates the collinearity effect by using only one ethnic diversity index below the threshold (the model use efi instead of epoi for value below the threshold).. Mavridis (2015) argued that the new model could separate the effects of EFI and EPOI and eliminate the collinearity problem between them.

\section{EMPIRICAL RESULTS}

Table 4.1 present the result of OLS estimation on the effects of ethnic diversity on expenditure inequality excluding all control variables. As expected, both ethnic fractionalization (efi) (column 1, 2 and 3) and ethnic polarization 
(epoi) (column 7, 8 and 9) have a positive and significant effect on expenditure inequality in Indonesia even though these variables only explain less than $10 \%$ of the variation in expenditure inequality.

Many researchers have argued that the rise in ethnic diversity would increase the number of social conflicts. But this is until a certain point, and after this point the rise in ethnic diversity would have a reverse effect (Montalvo and Reynal-Querol 2005, Horowitz 1985), namely, the relationship is not monotonous. To test whether such a relation exists in our data set, we introduced the square of these variables. Inclusion of the square of efi makes the coefficients for efi and efi ${ }^{2}$ insignificant (see columns 4, 5, and 6 in Table 4.1). In other words, ethnic fractionalization has a monotonous positive effect on expenditure inequality. Unlike ethnic fractionalization, ethnic polarization is found to have a significant nonlinear effect on expenditure inequality (see columns 10, 11, and 12 in Table 4.1). Since the coefficient of epoi is positive, while the coefficient of epoir is negative, ethnic polarization seems to have an inverted $U$ shaped relationship with expenditure inequality. Ethnic polarization first raises inequality, but after reaching a certain point, it lowers inequality.

We now examine the relationship between ethnic diversity and inequality by adding control variables. The results are presented in Table 4.2. Columns 1, 2, and 3 show that the coefficient of ethnic fractionation index (efi) turns to be negative, though it is not significant. The effect of ethnic polarization (epoi) remains positive, although the coefficient is not significant. However, the coefficient of epoi2 is significant and negative, indicating an inverted U-shaped relationship between ethnic polarization and expenditure inequality.

The author would like to thank Professor Takahiro Akita for his support in writing this paper Faculty of Economics and Business, Brawijaya University 
Table 4.1 OLS Estimation (without control variables)

\begin{tabular}{|c|c|c|c|c|c|c|c|c|c|c|c|c|}
\hline & $\begin{array}{c}(1) \\
\text { theil_I }\end{array}$ & $\begin{array}{c}(2) \\
\text { theil_t }\end{array}$ & $\begin{array}{c}\text { (3) } \\
\text { gini }\end{array}$ & $\begin{array}{c}(4) \\
\text { theil_I }\end{array}$ & $\begin{array}{c}(5) \\
\text { theil_t }\end{array}$ & $\begin{array}{l}6) \\
\text { gini }\end{array}$ & $\begin{array}{c}(7) \\
\text { theil_I }\end{array}$ & $\begin{array}{c}(8) \\
\text { theil_t }\end{array}$ & $\begin{array}{c}(9) \\
\text { gini }\end{array}$ & $\begin{array}{c}(10) \\
\text { theil_I }\end{array}$ & $\begin{array}{c}(11) \\
\text { theil_t }\end{array}$ & $\begin{array}{l}\text { (12) } \\
\text { gini }\end{array}$ \\
\hline $\begin{array}{l}\text { efi } \\
\text { efi }{ }^{2}\end{array}$ & $\begin{array}{l}0.0390^{* * *} \\
(0.00692)\end{array}$ & $\begin{array}{l}0.0393^{\star * *} \\
(0.00865)\end{array}$ & $\begin{array}{l}0.0392^{* * *} \\
(0.00673)\end{array}$ & $\begin{array}{c}0.00499 \\
(0.0274) \\
0.0406 \\
(0.0316)\end{array}$ & $\begin{array}{c}0.00671 \\
(0.0342) \\
0.0389 \\
(0.0396)\end{array}$ & $\begin{array}{c}0.00892 \\
(0.0266) \\
0.0362 \\
(0.0308)\end{array}$ & & & & & & \\
\hline $\begin{array}{l}\text { epoi } \\
\text { epoi² }\end{array}$ & & & & & & & $\begin{array}{c}0.0180^{* *} \\
(0.00770)\end{array}$ & $\begin{array}{c}0.0189^{* *} \\
(0.00954)\end{array}$ & $\begin{array}{c}0.0189^{* *} \\
(0.00750)\end{array}$ & $\begin{array}{c}0.179^{\star * *} \\
(0.0296) \\
-0.190^{\star * *} \\
(0.0338)\end{array}$ & $\begin{array}{c}0.179^{* \star *} \\
(0.0370) \\
-0.189^{\star * *} \\
(0.0423)\end{array}$ & $\begin{array}{c}0.177^{\star \star *} \\
(0.0288) \\
-0.187^{\star \star \star} \\
(0.0329)\end{array}$ \\
\hline Constant & $\begin{array}{c}0.132^{* * *} \\
(0.00346)\end{array}$ & $\begin{array}{c}0.154^{* * *} \\
(0.00433)\end{array}$ & $\begin{array}{c}0.282^{* * *} \\
(0.00337)\end{array}$ & $\begin{array}{c}0.136^{\star \star *} \\
(0.00444)\end{array}$ & $\begin{array}{c}0.158^{* * *} \\
(0.00555 \\
)\end{array}$ & $\begin{array}{c}0.285^{\star * *} \\
(0.00432 \\
)\end{array}$ & $\begin{array}{c}0.140^{* * *} \\
(0.00409)\end{array}$ & $\begin{array}{c}0.162^{* * *} \\
(0.00506)\end{array}$ & $\begin{array}{c}0.289^{\star * *} \\
(0.00398)\end{array}$ & $\begin{array}{c}0.120^{\star * \star} \\
(0.00530)\end{array}$ & $\begin{array}{c}0.142^{\star \star \star} \\
(0.00664 \\
)\end{array}$ & $\begin{array}{c}0.270^{\star * \star} \\
(0.00516 \\
)\end{array}$ \\
\hline $\begin{array}{l}\text { Obs } \\
\text { R- } \\
\text { squared }\end{array}$ & $\begin{array}{c}497 \\
0.060\end{array}$ & $\begin{array}{c}497 \\
0.040\end{array}$ & $\begin{array}{c}497 \\
0.064\end{array}$ & $\begin{array}{c}497 \\
0.063\end{array}$ & $\begin{array}{c}497 \\
0.042\end{array}$ & $\begin{array}{c}497 \\
0.067\end{array}$ & $\begin{array}{c}497 \\
0.011\end{array}$ & $\begin{array}{c}497 \\
0.008\end{array}$ & $\begin{array}{c}497 \\
0.013\end{array}$ & $\begin{array}{c}497 \\
0.071\end{array}$ & $\begin{array}{c}497 \\
0.047\end{array}$ & $\begin{array}{c}497 \\
0.073\end{array}$ \\
\hline
\end{tabular}

17

The author would like to thank Professor Takahiro Akita for his support in writing this paper Faculty of Economics and Business,

Brawijaya University 
Table 4.2 OLS Estimation

\begin{tabular}{|c|c|c|c|c|c|c|}
\hline & $\begin{array}{c}(1) \\
\text { theil_I }\end{array}$ & $\begin{array}{c}(2) \\
\text { theil_t }\end{array}$ & $\begin{array}{l}\text { (3) } \\
\text { gini }\end{array}$ & $\begin{array}{c}(4) \\
\text { theil_I }\end{array}$ & $\begin{array}{c}(5) \\
\text { theil_t }\end{array}$ & $\begin{array}{l}(6) \\
\text { gini }\end{array}$ \\
\hline In_mean_pcexp & $\begin{array}{l}0.868^{* *} \\
(0.376)\end{array}$ & $\begin{array}{c}0.783 \\
(0.508)\end{array}$ & $\begin{array}{c}1.090^{* * *} \\
(0.367)\end{array}$ & $\begin{array}{l}0.907^{* *} \\
(0.376)\end{array}$ & $\begin{array}{c}0.791 \\
(0.510)\end{array}$ & $\begin{array}{c}1.135^{* * *} \\
(0.367)\end{array}$ \\
\hline${ }_{2}^{\text {In_mean_pcexp }}$ & $-0.0286^{* *}$ & -0.0249 & $-0.0373^{\star \star *}$ & $-0.0301^{* *}$ & -0.0252 & $-0.0391^{* * *}$ \\
\hline & $(0.0142)$ & $(0.0192)$ & $(0.0138)$ & $(0.0142)$ & $(0.0193)$ & $(0.0139)$ \\
\hline mean_hsize & $\begin{array}{l}0.0174^{* * *} \\
(0.00461)\end{array}$ & $\begin{array}{l}0.0204^{* * *} \\
(0.00623)\end{array}$ & $\begin{array}{l}0.0171^{* * *} \\
(0.00450)\end{array}$ & $\begin{array}{l}0.0162^{* * *} \\
(0.00450)\end{array}$ & $\begin{array}{l}0.0192^{* * *} \\
(0.00610)\end{array}$ & $\begin{array}{l}0.0160^{* * *} \\
(0.00439)\end{array}$ \\
\hline prop_urban & $\begin{array}{l}-0.0242^{* * *} \\
(0.00858)\end{array}$ & $\begin{array}{c}-0.0250^{* \star} \\
(0.0116)\end{array}$ & $\begin{array}{l}-0.0222^{* * *} \\
(0.00837)\end{array}$ & $\begin{array}{l}-0.0248^{* * *} \\
(0.00847)\end{array}$ & $\begin{array}{c}-0.0254^{* *} \\
(0.0115)\end{array}$ & $\begin{array}{l}-0.0230^{* \star *} \\
(0.00825)\end{array}$ \\
\hline prop_male & $\begin{array}{l}-0.0176 \\
(0.0439)\end{array}$ & $\begin{array}{c}0.0114 \\
(0.0593)\end{array}$ & $\begin{array}{l}-0.00789 \\
(0.0428)\end{array}$ & $\begin{array}{l}-0.0270 \\
(0.0426)\end{array}$ & $\begin{array}{c}0.000457 \\
(0.0578)\end{array}$ & $\begin{array}{l}-0.0160 \\
(0.0416)\end{array}$ \\
\hline mean_age & $\begin{array}{l}0.00176^{\star *} \\
(0.000803)\end{array}$ & $\begin{array}{c}0.00334^{* \star *} \\
(0.00108)\end{array}$ & $\begin{array}{c}0.00170^{* *} \\
(0.000783)\end{array}$ & $\begin{array}{c}0.00188^{\star *} \\
(0.000824)\end{array}$ & $\begin{array}{c}0.00366^{\star * *} \\
(0.00112)\end{array}$ & $\begin{array}{l}0.00178^{* *} \\
(0.000804)\end{array}$ \\
\hline mean_edu & $\begin{array}{c}0.00714^{* * *} \\
(0.00177)\end{array}$ & $\begin{array}{c}0.00673^{* * *} \\
(0.00239)\end{array}$ & $\begin{array}{c}0.00791^{\star * *} \\
(0.00173)\end{array}$ & $\begin{array}{c}0.00650^{* * *} \\
(0.00177)\end{array}$ & $\begin{array}{l}0.00588^{* *} \\
(0.00240)\end{array}$ & $\begin{array}{c}0.00736^{* \star \star} \\
(0.00173)\end{array}$ \\
\hline In_total_pop & $\begin{array}{l}0.00492^{* *} \\
(0.00206)\end{array}$ & $\begin{array}{l}0.00717^{* *} \\
(0.00279)\end{array}$ & $\begin{array}{l}0.00462^{* *} \\
(0.00201)\end{array}$ & $\begin{array}{c}0.00543^{* * *} \\
(0.00206)\end{array}$ & $\begin{array}{l}0.00778^{* \star *} \\
(0.00280)\end{array}$ & $\begin{array}{l}0.00511^{* *} \\
(0.00201)\end{array}$ \\
\hline pov & $\begin{array}{l}0.244^{\star \star *} \\
(0.0260)\end{array}$ & $\begin{array}{l}0.270^{\star \star \star} \\
(0.0351)\end{array}$ & $\begin{array}{l}0.212^{\star * *} \\
(0.0254)\end{array}$ & $\begin{array}{l}0.242^{\star * *} \\
(0.0262)\end{array}$ & $\begin{array}{l}0.270^{\star * \star} \\
(0.0354)\end{array}$ & $\begin{array}{l}0.209^{* * *} \\
(0.0255)\end{array}$ \\
\hline efi & $\begin{array}{l}-0.00839 \\
(0.00759)\end{array}$ & $\begin{array}{c}-0.00578 \\
(0.0103)\end{array}$ & $\begin{array}{l}-0.00806 \\
(0.00740)\end{array}$ & & & \\
\hline $\begin{array}{l}\text { epoi } \\
\text { epoi2 }\end{array}$ & & & & $\begin{array}{c}0.0418 \\
(0.0278) \\
-0.0601^{\star *} \\
(0.0297)\end{array}$ & $\begin{array}{c}0.0582 \\
(0.0376) \\
-0.0721^{*} \\
(0.0402)\end{array}$ & $\begin{array}{c}0.0375 \\
(0.0271) \\
-0.0560^{\star} \\
(0.0290)\end{array}$ \\
\hline Constant & $\begin{array}{c}-6.569^{* * *} \\
(2.495)\end{array}$ & $\begin{array}{l}-6.223^{*} \\
(3.372)\end{array}$ & $\begin{array}{c}-7.836^{* * *} \\
(2.434)\end{array}$ & $\begin{array}{c}-6.820^{* * *} \\
(2.496)\end{array}$ & $\begin{array}{l}-6.281^{*} \\
(3.381)\end{array}$ & $\begin{array}{c}-8.123^{* * *} \\
(2.434)\end{array}$ \\
\hline $\begin{array}{l}\text { Observations } \\
\text { R-squared }\end{array}$ & $\begin{array}{c}497 \\
0.434\end{array}$ & $\begin{array}{c}497 \\
0.324\end{array}$ & $\begin{array}{c}497 \\
0.433\end{array}$ & $\begin{array}{c}497 \\
0.441\end{array}$ & $\begin{array}{c}497 \\
0.329\end{array}$ & $\begin{array}{c}497 \\
0.440\end{array}$ \\
\hline
\end{tabular}

Standard errors in parentheses ${ }^{* * *} p<0.01,{ }^{* *} p<0.05,{ }^{*} p<0.1$

Indonesia is an archipelagic country, and thus there are substantial differences among island regions in terms of culture, infrastructure, natural human and resources, and economic activities. Therefore, regional difference might have affected the relationship between ethnic diversity and inequality. In order to account for these differences, we introduce regional dummies in each model. Since there may be interaction effects between regions and ethnic diversity, we also include interaction terms between regional dummies and variables for ethnic diversity.
Table 4.3 shows the result of OLS estimation including regional dummies and ethnic fractionalization index (efi). Inclusion of regional dummies increases the R-squared by 10 percentage points. Moreover, the coefficients of all regional dummies are significant, indicating that there are significant structural differences among regions in the relationship between ethnic fractionalization and expenditure inequality. The sign of the coefficient for efi is still negative even after including regional dummies though it is not significant. If we 
include interaction terms between efi and regional dummies, the coefficients of the interaction terms for Java-Bali and East Indonesia are significant and negative. Though the coefficient of efi turns to be positive, the total effect of ethnic fractionalization on expenditure inequality (i.e., estimated coefficient of efi + estimated coefficient of interaction terms) is still negative in these two regions. This is not what we expected for the relationship between ethnic fractionalization and expenditure inequality.

Table 4.3 OLS Estimation (Fractionalization)

\begin{tabular}{|c|c|c|c|c|c|c|}
\hline VARIABLES & $\begin{array}{c}(1) \\
\text { theil_I }\end{array}$ & $\begin{array}{c}(2) \\
\text { theil_t }\end{array}$ & $\begin{array}{l}\text { (3) } \\
\text { gini }\end{array}$ & $\begin{array}{c}(4) \\
\text { theil_I }\end{array}$ & $\begin{array}{c}(5) \\
\text { theil_t }\end{array}$ & $\begin{array}{l}(6) \\
\text { gini }\end{array}$ \\
\hline In_mean_pcexp & $\begin{array}{c}1.858^{\star \star \star} \\
(0.341)\end{array}$ & $\begin{array}{c}1.906^{\star \star \star} \\
(0.484)\end{array}$ & $\begin{array}{c}2.054^{\star \star \star} \\
(0.332)\end{array}$ & $\begin{array}{c}2.003^{\star \star \star} \\
(0.344)\end{array}$ & $\begin{array}{c}2.097^{\star * *} \\
(0.489)\end{array}$ & $\begin{array}{c}2.181^{* * *} \\
(0.336)\end{array}$ \\
\hline${ }_{2}^{\text {In_mean_pcexp }}$ & $-0.0653^{\star \star *}$ & $-0.0663^{* * *}$ & $-0.0731^{* * *}$ & $-0.0703^{* * *}$ & $-0.0730^{* * *}$ & $-0.0775^{\star * *}$ \\
\hline & $(0.0129)$ & $(0.0182)$ & $(0.0125)$ & $(0.0129)$ & $(0.0184)$ & $(0.0127)$ \\
\hline mean_hsize & $\begin{array}{l}0.0158^{\star * *} \\
(0.00440)\end{array}$ & $\begin{array}{l}0.0195^{\star * *} \\
(0.00623)\end{array}$ & $\begin{array}{l}0.0155^{\star * *} \\
(0.00428)\end{array}$ & $\begin{array}{l}0.0177^{* * *} \\
(0.00442)\end{array}$ & $\begin{array}{l}0.0221^{* * *} \\
(0.00629)\end{array}$ & $\begin{array}{l}0.0171^{* * *} \\
(0.00432)\end{array}$ \\
\hline prop_urban & $\begin{array}{l}-0.0374^{* * *} \\
(0.00813)\end{array}$ & $\begin{array}{c}-0.0393^{\star * *} \\
(0.0115)\end{array}$ & $\begin{array}{l}-0.0344^{* \star *} \\
(0.00791)\end{array}$ & $\begin{array}{l}-0.0467^{\star * *} \\
(0.00838)\end{array}$ & $\begin{array}{c}-0.0504^{\star \star *} \\
(0.0119)\end{array}$ & $\begin{array}{c}-0.0426^{\star * \star} \\
(0.00819)\end{array}$ \\
\hline prop_male & $\begin{array}{l}-0.0257 \\
(0.0406)\end{array}$ & $\begin{array}{l}0.00307 \\
(0.0576)\end{array}$ & $\begin{array}{l}-0.0170 \\
(0.0395)\end{array}$ & $\begin{array}{l}-0.0472 \\
(0.0409)\end{array}$ & $\begin{array}{l}-0.0193 \\
(0.0582)\end{array}$ & $\begin{array}{c}-0.0362 \\
(0.0400)\end{array}$ \\
\hline mean_age & $\begin{array}{l}0.00196^{\star * *} \\
(0.000731)\end{array}$ & $\begin{array}{c}0.00362^{* * *} \\
(0.00104)\end{array}$ & $\begin{array}{l}0.00193^{* * *} \\
(0.000712)\end{array}$ & $\begin{array}{l}0.00234^{* * *} \\
(0.000758)\end{array}$ & $\begin{array}{c}0.00431^{* * *} \\
(0.00108)\end{array}$ & $\begin{array}{l}0.00224^{\star * *} \\
(0.000741)\end{array}$ \\
\hline mean_edu & $\begin{array}{c}0.00821^{* * *} \\
(0.00160)\end{array}$ & $\begin{array}{c}0.00754^{* \star *} \\
(0.00227)\end{array}$ & $\begin{array}{c}0.00912^{* * *} \\
(0.00156)\end{array}$ & $\begin{array}{c}0.00884^{\star \star *} \\
(0.00160)\end{array}$ & $\begin{array}{c}0.00818^{\star * *} \\
(0.00228)\end{array}$ & $\begin{array}{c}0.00970^{\star \star *} \\
(0.00156)\end{array}$ \\
\hline In_total_pop & $\begin{array}{c}0.00782^{* * *} \\
(0.00205)\end{array}$ & $\begin{array}{l}0.0107^{* * *} \\
(0.00290)\end{array}$ & $\begin{array}{c}0.00761^{* * *} \\
(0.00199)\end{array}$ & $\begin{array}{c}0.00697^{* * *} \\
(0.00203)\end{array}$ & $\begin{array}{c}0.00958^{* \star *} \\
(0.00288)\end{array}$ & $\begin{array}{c}0.00687^{* * *} \\
(0.00198)\end{array}$ \\
\hline pov & $\begin{array}{l}0.282^{* * *} \\
(0.0255)\end{array}$ & $\begin{array}{l}0.327^{* * *} \\
(0.0362)\end{array}$ & $\begin{array}{l}0.250^{* * *} \\
(0.0248)\end{array}$ & $\begin{array}{l}0.289^{* * *} \\
(0.0255)\end{array}$ & $\begin{array}{l}0.339^{* * *} \\
(0.0362)\end{array}$ & $\begin{array}{l}0.255^{\star * *} \\
(0.0249)\end{array}$ \\
\hline Java-Bali & $\begin{array}{l}0.0331^{* * *} \\
(0.00550)\end{array}$ & $\begin{array}{l}0.0359^{* * *} \\
(0.00779)\end{array}$ & $\begin{array}{l}0.0319^{* * *} \\
(0.00535)\end{array}$ & $\begin{array}{l}0.0515^{\star * *} \\
(0.00821)\end{array}$ & $\begin{array}{c}0.0587^{* * *} \\
(0.0117)\end{array}$ & $\begin{array}{l}0.0479^{* * *} \\
(0.00802)\end{array}$ \\
\hline Kalimantan & $\begin{array}{l}0.0305^{\star * *} \\
(0.00525)\end{array}$ & $\begin{array}{l}0.0344^{\star * *} \\
(0.00744)\end{array}$ & $\begin{array}{l}0.0329^{\star * *} \\
(0.00511)\end{array}$ & $\begin{array}{l}0.0340^{* *} \\
(0.0131)\end{array}$ & $\begin{array}{c}0.0506^{\star * *} \\
(0.0187)\end{array}$ & $\begin{array}{c}0.0344^{\star * *} \\
(0.0128)\end{array}$ \\
\hline Sulawesi & $\begin{array}{l}0.0469^{* * *} \\
(0.00496)\end{array}$ & $\begin{array}{l}0.0558^{* * *} \\
(0.00703)\end{array}$ & $\begin{array}{l}0.0452^{\star * \star} \\
(0.00483)\end{array}$ & $\begin{array}{l}0.0503^{* * *} \\
(0.00896)\end{array}$ & $\begin{array}{c}0.0597^{* * *} \\
(0.0127)\end{array}$ & $\begin{array}{l}0.0488^{* * *} \\
(0.00876)\end{array}$ \\
\hline East Indonesia & $\begin{array}{l}0.0416^{\star * \star} \\
(0.00502)\end{array}$ & $\begin{array}{l}0.0416^{* * *} \\
(0.00711)\end{array}$ & $\begin{array}{l}0.0411^{\star \star \star} \\
(0.00488)\end{array}$ & $\begin{array}{l}0.0730^{* * \star} \\
(0.00930)\end{array}$ & $\begin{array}{c}0.0825^{\star * *} \\
(0.0132)\end{array}$ & $\begin{array}{l}0.0681^{\star \star \star} \\
(0.00909)\end{array}$ \\
\hline efi & $\begin{array}{c}-0.0105 \\
(0.00708)\end{array}$ & $\begin{array}{l}-0.00820 \\
(0.0100)\end{array}$ & $\begin{array}{c}-0.0103 \\
(0.00689)\end{array}$ & $\begin{array}{c}0.0147 \\
(0.0113)\end{array}$ & $\begin{array}{c}0.0254 \\
(0.0160)\end{array}$ & $\begin{array}{c}0.0114 \\
(0.0110)\end{array}$ \\
\hline Jawa-Bali X efi & & & & $\begin{array}{c}-0.0394^{\star *} \\
(0.0172)\end{array}$ & $\begin{array}{l}-0.0464^{\star} \\
(0.0245)\end{array}$ & $\begin{array}{c}-0.0341^{* *} \\
(0.0168)\end{array}$ \\
\hline $\begin{array}{l}\text { Kalimantan X } \\
\text { efi }\end{array}$ & & & & -0.0111 & -0.0350 & -0.00675 \\
\hline & & & & $(0.0223)$ & $(0.0317)$ & $(0.0218)$ \\
\hline Sulawesi X efi & & & & $\begin{array}{l}-0.00436 \\
(0.0167)\end{array}$ & $\begin{array}{l}-0.00404 \\
(0.0238)\end{array}$ & $\begin{array}{r}-0.00534 \\
(0.0163)\end{array}$ \\
\hline EastIndo X efi & & & & $\begin{array}{c}-0.0629 \star \star \star \star \\
(0.0160)\end{array}$ & $\begin{array}{c}-0.0820^{\star \star \star} \\
(0.0227)\end{array}$ & $\begin{array}{c}-0.0541^{\star \star \star *} \\
(0.0156)\end{array}$ \\
\hline Constant & $\begin{array}{c}-13.31^{\star \star *} \\
(2.273)\end{array}$ & $\begin{array}{c}-13.89^{\star * *} \\
(3.221)\end{array}$ & $\begin{array}{c}-14.39^{* * *} \\
(2.211)\end{array}$ & $\begin{array}{c}-14.36^{* * *} \\
(2.288)\end{array}$ & $\begin{array}{c}-15.29^{* * *} \\
(3.255)\end{array}$ & $\begin{array}{c}-15.30^{* * *} \\
(2.237)\end{array}$ \\
\hline Observations & 497 & 497 & 497 & 497 & 497 & 497 \\
\hline R-squared & 0.567 & 0.432 & 0.569 & 0.584 & 0.450 & 0.582 \\
\hline
\end{tabular}


Table 4.4 shows the result of OLS estimation using regional dummies and ethnic polarization index (epoi). Inclusion of regional dummies increases the R-squared by about 12 percentage points. Moreover, the coefficients of all regional dummies are significant, indicating that there are significant structural differences among regions in the relationship between ethnic polarization and expenditure inequality. If we include interaction terms between epoi and regional dummies, the coefficients of the interaction terms for Java-Bali and East Indonesia are significant and negative. Though the coefficient of epoi turns to be positive and significant, the total effect of ethnic polarization on expenditure inequality (i.e., estimated coefficient of efi + estimated coefficient of interaction terms) is still negative in these two regions. This is not what we expected for the relationship between ethnic polarization and expenditure inequality.

Table 4.4 OLS Estimation (Polarization)

\begin{tabular}{|c|c|c|c|c|c|c|}
\hline VARIABLES & $\begin{array}{c}(1) \\
\text { theil_I }\end{array}$ & $\begin{array}{c}(2) \\
\text { theil_t }\end{array}$ & $\begin{array}{l}\text { (3) } \\
\text { gini }\end{array}$ & $\begin{array}{c}(4) \\
\text { theil_I }\end{array}$ & $\begin{array}{c}(5) \\
\text { theil_t }\end{array}$ & $\begin{array}{l}\text { (6) } \\
\text { gini }\end{array}$ \\
\hline In_mean_pcex & $1.787^{\star \star \star}$ & $1.809^{* * *}$ & $1.992^{* * *}$ & $1.908^{\star * *}$ & $1.920^{\star * *}$ & $2.115^{\star \star *}$ \\
\hline$p$ & $(0.343)$ & $(0.485)$ & $(0.334)$ & $(0.360)$ & $(0.510)$ & $(0.350)$ \\
\hline$\underset{p^{2}}{\ln \_ \text {mean_pcex }}$ & $-0.0627^{\star \star \star}$ & $-0.0628^{\star * *}$ & $-0.0709^{* * *}$ & $-0.0671^{* * *}$ & $-0.0667^{\star * *}$ & $-0.0754^{\star \star \star}$ \\
\hline & $(0.0129)$ & $(0.0183)$ & $(0.0126)$ & $(0.0136)$ & $(0.0192)$ & $(0.0132)$ \\
\hline mean_hsize & $\begin{array}{l}0.0152^{\star * *} \\
(0.00440)\end{array}$ & $\begin{array}{l}0.0190^{* * *} \\
(0.00621)\end{array}$ & $\begin{array}{l}0.0151^{* * *} \\
(0.00428)\end{array}$ & $\begin{array}{l}0.0188^{* * *} \\
(0.00459)\end{array}$ & $\begin{array}{l}0.0235^{\star * *} \\
(0.00651)\end{array}$ & $\begin{array}{l}0.0182^{* * *} \\
(0.00447)\end{array}$ \\
\hline prop_urban & $\begin{array}{l}-0.0371^{* * *} \\
(0.00815)\end{array}$ & $\begin{array}{c}-0.0392^{* * *} \\
(0.0115)\end{array}$ & $\begin{array}{l}-0.0341^{* * *} \\
(0.00793)\end{array}$ & $\begin{array}{l}-0.0428^{* * *} \\
(0.00849)\end{array}$ & $\begin{array}{c}-0.0455^{\star * *} \\
(0.0120)\end{array}$ & $\begin{array}{l}-0.0395^{\star * *} \\
(0.00826)\end{array}$ \\
\hline prop_male & $\begin{array}{l}-0.0528 \\
(0.0393)\end{array}$ & $\begin{array}{l}-0.0274 \\
(0.0556)\end{array}$ & $\begin{array}{l}-0.0419 \\
(0.0383)\end{array}$ & $\begin{array}{l}-0.0723^{*} \\
(0.0417)\end{array}$ & $\begin{array}{l}-0.0493 \\
(0.0591)\end{array}$ & $\begin{array}{l}-0.0597 \\
(0.0406)\end{array}$ \\
\hline mean_age & $\begin{array}{l}0.00231^{* * *} \\
(0.000751)\end{array}$ & $\begin{array}{l}0.00413^{* * *} \\
(0.00106)\end{array}$ & $\begin{array}{l}0.00223^{\star * *} \\
(0.000731)\end{array}$ & $\begin{array}{l}0.00221^{* * *} \\
(0.000791)\end{array}$ & $\begin{array}{l}0.00406^{* * *} \\
(0.00112)\end{array}$ & $\begin{array}{l}0.00205^{* * *} \\
(0.000769)\end{array}$ \\
\hline mean_edu & $\begin{array}{c}0.00750^{* * *} \\
(0.00161)\end{array}$ & $\begin{array}{c}0.00668^{\star \star *} \\
(0.00227)\end{array}$ & $\begin{array}{l}0.00848^{\star \star \star} \\
(0.00156)\end{array}$ & $\begin{array}{c}0.00822^{\star \star \star} \\
(0.00169)\end{array}$ & $\begin{array}{c}0.00744^{\star \star *} \\
(0.00239)\end{array}$ & $\begin{array}{c}0.00927^{* * *} \\
(0.00164)\end{array}$ \\
\hline In_total_pop & $\begin{array}{c}0.00705^{\star * *} \\
(0.00202)\end{array}$ & $\begin{array}{c}0.00982^{\star \star \star} \\
(0.00285)\end{array}$ & $\begin{array}{l}0.00690^{* * *} \\
(0.00196)\end{array}$ & $\begin{array}{c}0.00757^{\star \star \star} \\
(0.00203)\end{array}$ & $\begin{array}{l}0.0103^{* \star *} \\
(0.00288)\end{array}$ & $\begin{array}{c}0.00739^{\star * *} \\
(0.00198)\end{array}$ \\
\hline pov & $\begin{array}{l}0.285^{\star \star \star} \\
(0.0257)\end{array}$ & $\begin{array}{l}0.332^{* \star \star} \\
(0.0363)\end{array}$ & $\begin{array}{l}0.252^{\star * \star} \\
(0.0250)\end{array}$ & $\begin{array}{l}0.287^{\star * \star} \\
(0.0260)\end{array}$ & $\begin{array}{l}0.333^{\star * *} \\
(0.0368)\end{array}$ & $\begin{array}{l}0.252^{\star * \star} \\
(0.0253)\end{array}$ \\
\hline Java-Bali & $\begin{array}{l}0.0366^{\star * *} \\
(0.00558)\end{array}$ & $\begin{array}{l}0.0408^{* * *} \\
(0.00789)\end{array}$ & $\begin{array}{l}0.0350^{* * *} \\
(0.00543)\end{array}$ & $\begin{array}{c}0.0598^{* * *} \\
(0.0123)\end{array}$ & $\begin{array}{c}0.0675^{\star * *} \\
(0.0174)\end{array}$ & $\begin{array}{c}0.0577^{* * *} \\
(0.0120)\end{array}$ \\
\hline Kalimantan & $\begin{array}{l}0.0303^{\star \star \star} \\
(0.00526)\end{array}$ & $\begin{array}{l}0.0342^{\star \star \star} \\
(0.00744)\end{array}$ & $\begin{array}{l}0.0328^{* * *} \\
(0.00512)\end{array}$ & $\begin{array}{c}0.0293 \\
(0.0290)\end{array}$ & $\begin{array}{c}0.0348 \\
(0.0411)\end{array}$ & $\begin{array}{c}0.0281 \\
(0.0282)\end{array}$ \\
\hline Sulawesi & $\begin{array}{l}0.0457^{\star \star \star} \\
(0.00503)\end{array}$ & $\begin{array}{l}0.0549^{\star \star \star} \\
(0.00711)\end{array}$ & $\begin{array}{l}0.0441^{* * *} \\
(0.00490)\end{array}$ & $\begin{array}{c}0.0541^{* * *} \\
(0.0164)\end{array}$ & $\begin{array}{l}0.0569^{* *} \\
(0.0232)\end{array}$ & $\begin{array}{c}0.0546^{\star * *} \\
(0.0159)\end{array}$ \\
\hline East Indonesia & $\begin{array}{l}0.0401^{* * *} \\
(0.00509)\end{array}$ & $\begin{array}{l}0.0408^{\star * *} \\
(0.00720)\end{array}$ & $\begin{array}{l}0.0396^{* \star \star} \\
(0.00495)\end{array}$ & $\begin{array}{c}0.0767^{* * *} \\
(0.0171)\end{array}$ & $\begin{array}{c}0.0838^{* * *} \\
(0.0242)\end{array}$ & $\begin{array}{c}0.0728^{* * *} \\
(0.0167)\end{array}$ \\
\hline $\begin{array}{l}\text { epoi } \\
\text { Java-BaliXepoi }\end{array}$ & $\begin{array}{c}0.0218 \\
(0.0254)\end{array}$ & $\begin{array}{c}0.0349 \\
(0.0360)\end{array}$ & $\begin{array}{c}0.0180 \\
(0.0248)\end{array}$ & $\begin{array}{c}0.106^{\star \star} \\
(0.0445) \\
-0.109^{\star} \\
(0.0617)\end{array}$ & $\begin{array}{c}0.119^{\star} \\
(0.0630) \\
-0.120 \\
(0.0875)\end{array}$ & $\begin{array}{c}0.105^{\star \star} \\
(0.0433) \\
-0.124^{\star \star} \\
(0.0601)\end{array}$ \\
\hline $\begin{array}{l}\text { KalimantanXep } \\
\text { oi }\end{array}$ & & & & -0.0611 & -0.0523 & -0.0529 \\
\hline SulawesiXepoi & & & & $\begin{array}{c}(0.110) \\
-0.0313 \\
(0.0773)\end{array}$ & $\begin{array}{l}(0.155) \\
0.0244 \\
(0.110)\end{array}$ & $\begin{array}{l}(0.107) \\
-0.0499 \\
(0.0752)\end{array}$ \\
\hline
\end{tabular}




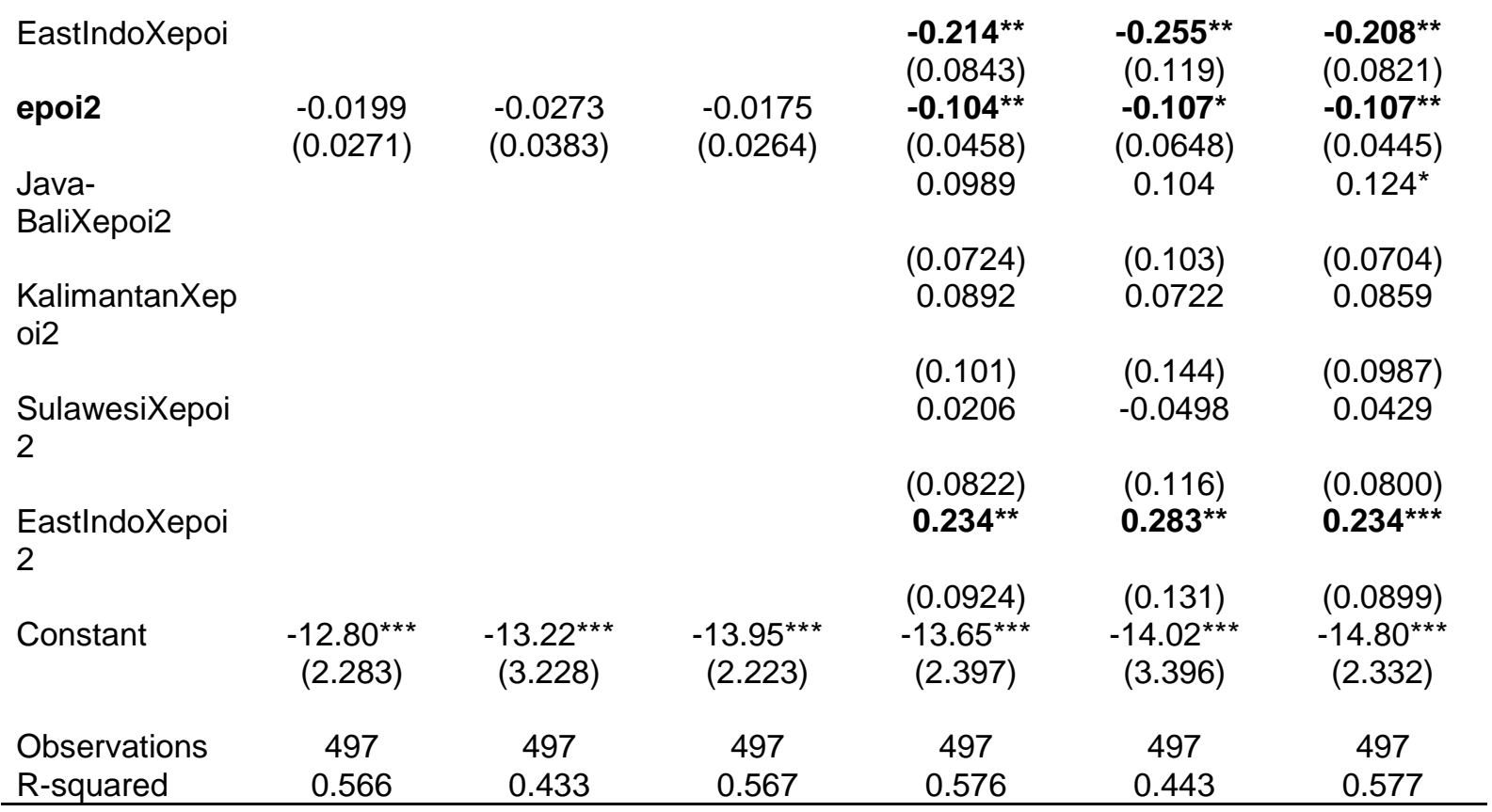

Ethnic fractionalization and polarization are supposed to have a different effect on economic performance. However, it is difficult to detect their differential effects since there is a collinear relationship between these two ethnic variables. In order to account for this collinear relationship, we conduct a regression analysis using the model in equation (2). The result is presented in Table 4.5. According to columns 1 , 2 and 3 , where no control variables are included, the coefficient of the two variables, divers and frac, are positive and significant, while the coefficient of the variable, polar, is negative and significant. In other words, without control variables, these three variables have a significant effect on expenditure inequality. However, as shown in columns 4,5 and 6 , if we include control variables, the coefficients of the variables, divers, and frac, turn out to be insignificant, though the sign of the coefficients is still positive. Meanwhile, the coefficient of polar is still significant and negative. From these observations, ethnic polarization has a stronger effect on expenditure inequality.

We examined the relationship between ethnic diversity and expenditure inequality by adding regional dummies to the model. According to table 4.5 columns 1,2 and 3 , the coefficients of the two variables divers and frac are negative, while the coefficient of the variable polar is positive, and all of them are insignificant. In addition, the coefficients of all regional dummies are significant, indicating that there are significant structural differences between regions in the relationship between ethnic diversity and expenditure inequality. This result is equivalent to the results of the previous calculation using equation (1). 
Table 4.5 OLS Estimation

\begin{tabular}{|c|c|c|c|c|c|c|c|c|c|}
\hline VARIABLES & $\begin{array}{c}(1) \\
\text { theil I }\end{array}$ & $\begin{array}{l}(2) \\
\text { theil } t\end{array}$ & $\begin{array}{l}(3) \\
\text { aini }\end{array}$ & $\begin{array}{r}(4) \\
\text { theil I }\end{array}$ & $\begin{array}{l}(5) \\
\text { theil } t\end{array}$ & $\begin{array}{l}(6) \\
\text { aini }\end{array}$ & $\begin{aligned}(7) \\
\text { theil I }\end{aligned}$ & $\begin{array}{l}(8) \\
\text { theil } t\end{array}$ & $\begin{array}{l}\text { (9) } \\
\text { gini }\end{array}$ \\
\hline divers $<0.6$ & $\begin{array}{c}\mathbf{0 . 0 7 2 2}^{\star \star \star *} \\
(0.0159)\end{array}$ & $\begin{array}{c}\mathbf{0 . 0 6 7 5} 5^{\star \star \star} \\
(0.0201)\end{array}$ & $\begin{array}{c}\mathbf{0 . 0 7 3 9} \\
(0.0155)\end{array}$ & $\begin{array}{c}0.0128 \\
(0.0149)\end{array}$ & $\begin{array}{c}0.0145 \\
(0.0202)\end{array}$ & $\begin{array}{c}0.0134 \\
(0.0145)\end{array}$ & $\begin{array}{r}-0.00520 \\
(0.0138)\end{array}$ & $\begin{array}{r}-0.00538 \\
(0.0196)\end{array}$ & $\begin{array}{l}-0.00413 \\
(0.0135)\end{array}$ \\
\hline polar $>0.6$ & $-0.0323^{\star * *}$ & $-0.0303^{\star \star \star}$ & $-0.0320^{\star \star *}$ & $-0.0151^{\star *}$ & -0.0128 & $-0.0155^{\star \star \star}$ & 0.00211 & 0.00581 & 0.000963 \\
\hline & $(0.00733)$ & (0.00924) & $(0.00713)$ & $(0.00601)$ & $(0.00816)$ & $(0.00586)$ & $(0.00564)$ & (0.00799) & $(0.00549)$ \\
\hline frac $>0.6$ & $\begin{array}{l}\mathbf{0 . 0 6 0 3}^{\star \star \star} \\
(0.00836)\end{array}$ & $\begin{array}{c}\mathbf{0 . 0 5 9 2}{ }^{\star \star \star} \\
(0.0105)\end{array}$ & $\begin{array}{l}\mathbf{0 . 0 6 0 4}^{\star \star \star} \\
(0.00813)\end{array}$ & $\begin{array}{c}0.00354 \\
(0.00897)\end{array}$ & $\begin{array}{l}0.00450 \\
(0.0122)\end{array}$ & $\begin{array}{c}0.00415 \\
(0.00874)\end{array}$ & $\begin{array}{c}-0.0115 \\
(0.00861)\end{array}$ & $\begin{array}{l}-0.0122 \\
(0.0122)\end{array}$ & $\begin{array}{c}-0.0105 \\
(0.00838)\end{array}$ \\
\hline In mean pcexp & & & & $\begin{array}{l}0.907^{\star *} \\
(0.375)\end{array}$ & $\begin{array}{c}0.812 \\
(0.509)\end{array}$ & $\begin{array}{c}1.130^{* * *} \\
(0.365)\end{array}$ & $\begin{array}{c}1.853^{* \star *} \\
(0.342)\end{array}$ & $\begin{array}{c}1.905^{\star * *} \\
(0.484)\end{array}$ & $\begin{array}{c}2.047^{\star \star *} \\
(0.333)\end{array}$ \\
\hline In mean pcexp & & & & $\begin{array}{c}-0.0301^{\star *} \\
(0.0142)\end{array}$ & $\begin{array}{l}-0.0260 \\
(0.0192)\end{array}$ & $\begin{array}{c}-0.0389^{* * *} \\
(0.0138)\end{array}$ & $\begin{array}{c}-0.0651^{* * *} \\
(0.0129)\end{array}$ & $\begin{array}{c}-0.0662^{\star * *} \\
(0.0183)\end{array}$ & $\begin{array}{c}-0.0728^{\star \star *} \\
(0.0125)\end{array}$ \\
\hline mean hsize & & & & $\begin{array}{l}0.0165^{\star \star \star} \\
(0.00462)\end{array}$ & $\begin{array}{l}0.0198^{\star \star \star} \\
(0.00626)\end{array}$ & $\begin{array}{l}0.0162^{* \star *} \\
(0.00450)\end{array}$ & $\begin{array}{l}0.0160^{* * *} \\
(0.00441)\end{array}$ & $\begin{array}{l}0.0198^{* * *} \\
(0.00625)\end{array}$ & $\begin{array}{l}0.0158^{* \star *} \\
(0.00429)\end{array}$ \\
\hline prop urban & & & & $-0.0232^{* * \star}$ & $-0.0241^{* *}$ & $-0.0213^{* *}$ & $-0.0375^{* * *}$ & $-0.0396^{* * *}$ & $-0.0344^{\star \star *}$ \\
\hline prop male & & & & $\begin{array}{c}(0.00850) \\
-0.0209 \\
(0.0437\end{array}$ & 0.00882 & $\begin{array}{c}(0.00834) \\
-0.0113 \\
(0.0426)\end{array}$ & $\begin{array}{c}(0.00814) \\
-0.0242 \\
(0.0408)\end{array}$ & 0.00680 & $\begin{array}{c}(0.00793) \\
-0.0162 \\
(0.0397)\end{array}$ \\
\hline mean age & & & & $0.00173^{\star *}$ & $0.00335^{\star \star \star *}$ & $0.00167^{\star *}$ & $0.00205^{\star * *}$ & $0.00377^{\star * *}$ & $0.00201^{* * *}$ \\
\hline - & & & & $(0.000806)$ & $(0.00109)$ & $(0.000785)$ & $(0.000737)$ & $(0.00104)$ & $(0.000717)$ \\
\hline mean edu & & & & $\begin{array}{c}0.00659^{\star * *} \\
(0.00178)\end{array}$ & $\begin{array}{c}0.00625^{\star * *} \\
(0.00241)\end{array}$ & $\begin{array}{c}0.00735^{\star * *} \\
(0.00173)\end{array}$ & $0.00822^{* * *}$ & $\begin{array}{l}0.00767^{* * *} \\
(0002 ? 9)\end{array}$ & $0.00910^{* \star \star}$ \\
\hline In total pop & & & & $0.00527^{\star *}$ & $0.00754^{\star * *}$ & $0.00497^{* *}$ & $0.00805^{* * *}$ & $0.0110^{* * *}$ & $0.00781^{* * *}$ \\
\hline pov & & & & $\begin{array}{c}(0.00208) \\
0.241^{* * *}\end{array}$ & $\begin{array}{c}(0.00282) \\
0.268^{* *}\end{array}$ & $\begin{array}{c}(0.00203) \\
0.208^{* *}\end{array}$ & $\begin{array}{c}(0.00206) \\
0.285^{\star * \star}\end{array}$ & & $\begin{array}{c}(0.00200) \\
0.252^{* * *}\end{array}$ \\
\hline & & & & $(0.0261)$ & $(0.0355)$ & $(0.0255)$ & $(0.0257)$ & $(0.0364)$ & $(0.0250)$ \\
\hline Java-Bali & & & & & & & $0.0337^{* * *}$ & $0.0368^{* * *}$ & $0.0324^{* * *}$ \\
\hline Kalimantan & & & & & & & $0.0304^{* * *}$ & $0.0344^{\star \star *}$ & $0.0329^{* \star *}$ \\
\hline & & & & & & & (0.00525) & (0.00744) & $(0.00511)$ \\
\hline Sulawesi & & & & & & & $0.0475^{\star * *}$ & $0.0572^{* \star *}$ & $0.0456^{* * *}$ \\
\hline & & & & & & & $(0.00508)$ & $(0.00720)$ & $(0.00495)$ \\
\hline East Indonesia & & & & & & & $\begin{array}{l}0.0425^{\star \star \star} \\
(0.00529)\end{array}$ & $\begin{array}{l}0.0438^{\star \star \star} \\
(0.00749)\end{array}$ & $\begin{array}{l}0.0417^{\star \star \star} \\
(0.00515)\end{array}$ \\
\hline Constant & $\begin{array}{l}0.131^{\star * *} \\
(0.00386)\end{array}$ & $\begin{array}{c}0.154^{* * *} \\
(0.00487)\end{array}$ & $\begin{array}{c}0.280^{* * *} \\
(0.00375)\end{array}$ & $\begin{array}{c}-6.813^{\star * *} \\
(2.488)\end{array}$ & $\begin{array}{l}-6.404^{\star} \\
(3.375)\end{array}$ & $\begin{array}{c}-8.088^{* * *} \\
(2.425)\end{array}$ & $\begin{array}{c}-13.30^{\star * *} \\
(2.277)\end{array}$ & $\begin{array}{c}-13.92^{* * *} \\
(3.225)\end{array}$ & $\begin{array}{c}-14.36^{\star * \star} \\
(2.216)\end{array}$ \\
\hline Observations & 497 & 497 & 497 & 497 & 497 & 497 & 497 & 497 & 497 \\
\hline R-squared & 0.097 & 0.062 & 0.102 & 0.441 & 0.328 & 0.441 & 0.568 & 0.433 & 0.569 \\
\hline
\end{tabular}

Standard errors in parentheses ${ }^{* * *} p<0.01,{ }^{* *} p<0.05,{ }^{*} p<0.1$ 
The negative coefficient of divers indicated that ethnic diversity has a negative relationship with expenditure inequality when the indexes of efi and epoi are low. When the ethnic fractionalization index is high, stated by the positive coefficient of frac, the negative relationship remains. However, the polar coefficient is positive, indicating that the ethnic polarization index has a positive relationship with expenditure inequality when the epoi is high. The findings of both equations (1) and (2) indicate unexpected outcomes, different from the hypothesis. This result differs from the earlier study by Dincer and Hotard (2011) that showed a positive and significant relationship between income inequality and ethnic diversity.

\section{CONCLUSION}

This thesis tries to examine the effect of ethnic diversity on expenditure inequality in Indonesia. There are only a few studies on ethnicity in Indonesia, and they are centered on ethnicity itself without considering the economic distribution. This study, hopefully, will broaden the discussion on ethnicity in Indonesia by exploring expenditure inequality.

This paper used two types of data, namely SUSENAS surveys and population census data provided by Statistics Indonesia. The latest population census was conducted in 2010; it determined the ethnic variable to calculate the ethnic fractionalization index and ethnic polarization index, which was constructed by Arifin et al. (2015), while expenditure inequality was calculated using SUSENAS 2010 data.

We found that without the control variable, the ethnic fractionalization index is positive and significant in affecting expenditure inequality in Indonesia. Unlike the ethnic fractionalization index, the ethnic polarization index has a positive and significant coefficient, while the square of ethnic polarization index has a negative and significant coefficient. In other words, ethnic polarization and expenditure inequality have an inverted U-shaped relationship. However, the effect of ethnic diversity is less significant when control variables are added to the estimation; ethnic fractionalization and ethnic polarization lose their significance while the square of ethnic polarization is still negatively significant in affecting expenditure inequality. This result is different from the research conducted by Dincer and Hotard (2011) that found ethnic and religious diversity significantly affects income inequality

Moreover, the effect of ethnic diversity loses its significance when incorporating regional dummies into the estimation. We found that all regional dummies significantly affected inequality and diminished the ethnic diversity effect. These findings are in line with Muttaqien et al.'s (2018) estimation that demonstrated, using IFLS data, ethnicity becomes less significant to earnings polarization when using regional characteristic covariates.

Furthermore, the inclusion of the interaction term between ethnic diversity proxy and regional dummies reveals an unexpected result. Though not significant, both interactions of the ethnic fractionalization index or the ethnic polarization index with regional dummies show a negative relationship. The result shows that the more diverse the districts, the less the level of expenditure inequality. Dincer and Hotard 
(2011) argued that there is a link between ethnic and religious diversity and social conflicts that leads to income inequality. Following Dincer and Hotard's (2011) argument, our result shows that the more the ethnic diversity in the district, the less the incidents of conflict in that district, which leads to less expenditure inequality. This claim is supported by Mavridis (2015), who stated that Indonesians at high ethnic diversity districts are becoming more tolerant.

Several policy recommendations can be provided based on the findings of this study. First, as regional dummies are more significant than ethnic diversity, the policymaker can concentrate on establishing economic equality between regions in Indonesia. One of the ways is by utilizing the decentralization policy that has existed since the reform era. Instead of using this advantage as an opportunity to conduct corruption, local governments can use decentralization as an opportunity to improve the welfare of their region. Second, in certain areas, such as Java-Bali and East Indonesia, ethnic diversity has a significant effect on inequality expenditure. Therefore, policymaker should be mindful of the diversity and bring the importance of unity and tolerance in issuing a policy.

We acknowledge that there are several limitations to this study. First, because the latest comprehensive ethnicity data only covered in 2010 , the result of this study might be could not describe the latest condition due to population changing and migration among the regions. Second, the used cross-sectional model prevents us from seeing the causal effect between ethnic diversity and expenditure inequality.

\section{REFERENCES}

Akita, T, Lukman R.A., Yamada Y. (1999). Inequality in the Distribution of Household Expenditures in Indonesia: a Theil Decomposition Analysis. The Developing Economies, XXXVII-2,197221.

Akita, T., and Alisjahbana, A. (2002). Regional income inequality in Indonesia and the initial impact of the economic crisis. Bulletin of Indonesian Economic Studies, 38, 201-22.

Akita, T., and Miyata, S. (2008). Urbanization, educational expansion, and expenditure inequality in Indonesia in 1996, 1999, and 2002. Journal of the Asia Pacific Economy, 13, 147-67.

Akita, T. (2017). Educational expansion and the role of education in expenditure inequality in Indonesia since the 1997 financial crisis. Social Indicators Research, 130, 1165-1186.

Alesina, A., \& Ferrara, E. L. (2005). Ethnic diversity and economic performance. Journal of economic literature, 43(3), 762-800.

Alesina, A., Michalopoulos, S., Papaioannou, E. (2016). Ethnic Inequality. Journal of Political Economy, 124, no. 2.

Anand, S. (1983). Inequality and Poverty in Malaysia: Measurement and Decomposition. New York: Oxford University Press.

Ananta, A., Arifin, E. N., Hasbullah, M. S., Handayani, N. B., \& Pramono, A. (2015). Demography of Indonesia's ethnicity. Institute of Southeast Asian Studies. 
Arifin, E. N., Ananta, A., Wilujeng Wahyu Utami, D. R., Budi Handayani, N., \& Pramono, A. (2015). Quantifying Indonesia's ethnic diversity: statistics at national, provincial, and district levels. Asian Population Studies, 11(3), 233-256.

Barron, P. and Madden, D. 2004. Violence \& Conflict Resolution in "Non-Conflict" Regions: The Case of Lampung, Indonesia. World bank report.

Chadha, N., \& Nandwani, B. (2018). Ethnic fragmentation, public good provision and inequality in India, 19882012. Oxford Development Studies, 46(3), 363-377.

Dincer, O. C., \& Hotard, M. J. (2011). Ethnic and religious diversity and income inequality. Eastern Economic Journal, 37(3), 417-430.

Easterly, W., \& Levine, R. (1997). Africa's growth tragedy: policies and ethnic divisions. The quarterly journal of economics, 112(4), 1203-1250.

Esteban, J. M., \& Ray, D. (1994). On the measurement of polarization. Econometrica: Journal of the Econometric Society, 819-851.

Esteban, J., Mayoral, L., \& Ray, D. (2012). Ethnicity and conflict: An empirical study. American Economic Review, 102(4), 1310-42.

Fitrani, F., Hofman, B., \& Kaiser*, K. (2005). Unity in diversity? The creation of new local governments in a decentralising Indonesia. Bulletin of Indonesian Economic Studies, 41(1), 57-79.

Gayatri, I. H. (2011). Nationalism, Democratisation and Primordial Sentiment in Indonesia: Problems of Ethnicity versus Indonesian-ness (the cases of Aceh, Riau, Papua and Bali). Journal of Indonesian Social Sciences and Humanities, 3, 189-203.

Gradin, C. (2015). Rural Poverty and Ethnicity in China. In Measurement of Poverty, Deprivation, and Economic Mobility, 221-247.

Hayashi, M., Kataoka, M., \& Akita, T. (2014). Expenditure Inequality in Indonesia, 2008-2010: A Spatial Decomposition Analysis and the Role of Education. Asian Economic Journal, 28(4), 389-411.

Horowitz, D., 1985. Ethnic Groups in Conflict. University of California Press

Imai, K.S., Gaiha, R., Kang, W. (2011). Poverty, Inequality and ethnic minorities in Vietnam. International Review of Applied Economics, 25:3, 249-282.

Kuznets, S. (1955). Economic growth and income inequality. The American economic review, 1-28.

Mavridis, D. (2015). Ethnic diversity and social capital in Indonesia. World Development, 67, 376-395.

Muller, C. (2016). Ethnic inequality and community activities in Indonesia (No. 2016/170). WIDER Working Paper.

Montalvo, J.G., \& Reynal-Querol, M. (2005). Ethnic diversity and economic development. Journal of Development economics, 76(2), 293-323.

Muttaqien, A., Sologon, D., \& O'Donoghue, C. (2018). Earnings polarization, ethnicity, and regional perspective in Indonesia (No. 2018/106). WIDER Working Paper.

Reynal-Querol, M. (2002). Ethnicity, Political Systems, and Civil Wars. Journal of Conflict Resolution, 29-54. 
Sagala, P., Akita, T., \& Yusuf, A. A. (2014). Urbanization and expenditure inequality in Indonesia: testing the Kuznets hypothesis with provincial panel data. Letters in Spatial and Resource Sciences, 7(3), 133-147.

Tadjoeddin, M. Z. et al. (2001). Regional Disparity and Vertical Conflict in Indonesia. Journal of the Asia Pacific Economy, 6(3), 283-304.

van de Walle, D., \& Gunewardena, D. (2001). Sources of ethnic inequality in Viet Nam. Journal of Development Economics, 65(1), 177-207.

Yusuf, A. A., \& Sumner, A. (2015). Growth, poverty, and inequality under Jokowi. Bulletin of Indonesian Economic Studies, 51(3), 323-348.

Yusuf, A. A., Sumner, A., \& Rum, I. A. (2014). Twenty years of expenditure inequality in Indonesia, 1993-2013. Bulletin of Indonesian Economic Studies, 50(2), 243-254. 